\title{
ANALISIS MODEL ELEMEN HINGGA PERKUATAN LERENG MENGGUNAKAN SOIL NAILING (STUDI KASUS: LERENG DAERAH LAHAT, SUMATERA SELATAN)
}

\author{
Syahidus SYUHADA1*, ZAKARIA2, Rahmat KURNIAWAN1, Erdina Tyagita UTAMI 1 \\ 1Program Studi Teknik Sipil, Jurusan Teknologi Infrastruktur dan Kewilayahan, Institut Teknlogi \\ Sumatera, Lampung Selatan, Indonesia \\ 2Alumni Program Studi Teknik Sipil, Jurusan Teknologi Infrastruktur dan Kewilayahan, Institut Teknlogi \\ Sumatera, Lampung Selatan, Indonesia \\ *Email korespondensi: syahidus.syuhada@si.itera.ac.id \\ [diterima: 24 April 2020, disetujui: 29 Mei 2020]
}

\begin{abstract}
Soil nailing is a method for solving landslide problems, both on existing slopes and walls during excavation. Conventional soil nailing design procedures based on limit equilibrium methods fail to address the complex mutual interaction between its main components, which affects the performance of soil nail. Therefore, it is needed for the practical design of numerical solutions that can accommodate the requirement. One of the numerical techniques that often used is the finite element method (finite element). In the finite element method application, there are no specific options for modeling soil nailing reinforcement. Soil nailings are modeled with the material sets available in the finite element program, namely plate, anchor (node to node), and geogrid. The slope properties used in this study are secondary data located in Suban, Lahat, South Sumatra. The slope variation $\left(0 \circ, 10 \circ, 15 \circ, 20_{\circ}\right)$ and the reinforcement length $(3 \mathrm{~m}-10 \mathrm{~m})$ were analyzed. Material set node to node and material set geogrid have relatively similar FS values. The material set plate gives the smallest FS results among the three material sets. The difference between the FS results using the geogrid/node to node material set and the material set plate is $0.02 \%-5.12 \%$. A significant increase in FS value occurs at an angle of 0 o to 15 o, but at an angle of 15 o to 20 o the increase in FS value that arises is not too significant, only occurs by $1 \%-5 \%$. In this case, the optimal installation of soil nailing at an angle of 15.
\end{abstract}

Keywords: Soil nailing, plate model, node to node model, geogrid model, safety factor.

\section{INTISARI}

Soil Nailing adalah salah satu metoda untuk menanggulangi masalah kelongsoran, baik pada lereng eksisting maupun dinding saat proses penggalian. Prosedur desain soil nailing berdasarkan metoda konvensional gagal dalam mengatasi interaksi timbal balik yang kompleks antara komponen utama yang mepengaruhi kinerja soil nail. Oleh karena itu dibutuhkan dalam desain praktis solusi numerik yang dapat mengakomodir permasalahan tersebut. Salah satu teknik numerik yang sering digunakan adalah metoda elemen hingga (finite element). Dalam program metoda elemen hingga tidak ada pilihan khusus untuk memodelkan perkuatan soil nailing. Soil nail dimodelkan dengan material set yang tersedia pada program elemen hingga, yaitu plate, anchor (node to node) dan geogrid. Data lereng yang digunakan merupakan data sekunder yang berlokasi di Suban, Lahat, Sumatera Selatan. Dilakukan analisis dengan variasi kemiringan lereng $\left(0_{o}, 10_{o}, 15 o, 20_{o}\right)$ dan panjang perkuatan $(3 \mathrm{~m}-10 \mathrm{~m})$. Material set node to node dan material set geogrid memiliki nilai FS yang relatif sama. Material set plate memberikan hasil FS paling kecil diantara ketiga material set. Perbedaan antara hasil FS menggunakan material set geogrid/node to node dengan material set plate adalah sebesar $0.02 \%-5.12 \%$. Kenaikan nilai FS signifikan terjadi pada sudut 0 o sampai 15 , namun pada sudut 15 o ke 20。 kenaikan nilai FS yang terjadi tidak terlalu signifikan hanya terjadi sebesar $1 \%$ - 5\%. Pada kasus ini, pemasangan soil nailing yang ideal ada pada sudut 15 o.

Kata kunci: Soil nailing, model plate, model node to node, model geogrid, faktor keamanan. 


\section{PENDAHULUAN}

Indonesia merupakan negara kepulauan yang memiliki beragam kondisi geografis yang beragam. Kondisi geografis yang beragam ini merupakan suatu tantangan untuk mengembangkan pembangunan. Potensi bahaya yang mungkin akan banyak timbul dari permasalahan geografis tersebut adalah terdapat banyak lereng-lereng yang berpotensi untuk timbulnya bencana tanah longsor.

Untuk menghadapi masalah kelongsoran lereng, banyak metoda yang digunakan, misalnya mengubah geometri dari lereng, membuat perkuatan dinding penahan tanah, vegetasi, dan masih banyak lainnya. Salah satu, metoda yang banyak digunakan adalah soil nailing. Metode ini berawal dari metoda untuk perkuatan tunneling pada tahun 1960an, yaitu dengan menggunakan lapisan fleksibel tipis dan diperkuat dengan baut atau nailing (Ortigao, 2004). Soil nailing juga dapat dipasang pada lereng alami atau lereng buatan (Han, 2015). Oleh karena itu soil nailing dapat dipertimbangkan sebagai salah satu metoda yang digunakan untuk mencegah kelongsoran.

Prosedur desain soil nailing berdasarkan metoda konvensional gagal dalam mengatasi interaksi timbal balik yang kompleks antara komponen utama yang mepengaruhi kinerja soil nail (Midhula, 2015). Akibatnya dalam desain praktis, solusi numerik dengan teknik numerik cenderung banyak digunakan karena dapat mengakomodir permasalahan tersebut. Salah satu teknik numerik yang sering digunakan adalah metoda elemen hingga (finite element).

Untuk memodelkan perkuatan soil nailng tidak tersedia di dalam program elemen hingga, sehingga digunakan pendekatan material untuk memodelkan hasil perkuatan yang mendekati perilaku dari soil naling. Telah banyak dimodelkan struktur perkuatan lereng soil nailing dengan model plate dan geogrid. Tersedia pilihan elemen node to node (anchor) pada program FEM yang merupakan suatu material spring yang memodelkan suatu pengaku antara dua titik (Brinkgreve, 2002). Karena soil nailing juga merupakan struktur pengaku, maka analisis soil nailing menggunakan juga dilakukan dengan material set node to node.

Pada penelitian ini digunakan data sekunder dari lereng di daerah Suban, Lahat, Sumatera Selatan yang mengalami kelongsoran. Dengan menggunakan data lereng tersebut dilakukan analisis perkuatan tanah soil nailing pada software elemen hingga dengan model plate, model node to node, dan model geogrid.

\section{TINJAUAN PUSTAKA}

\section{Analisis Stabilitas Lereng dengan Metoda Elemen Hingga}

Lereng merupakan tanah yang memiliki kondisi geometri yang tidak rata. Lereng terbagi dalam dua jenis yaitu lereng alami dan lereng alam. Kestabilan dari lereng ditentukan oleh besarnya kuat geser tanah. Untuk mengetahui stabil atau tidaknya lereng tersebut, dapat dilihat dari besarnya nilai $F S$ (Faktor Keamanan). FS adalah perbandingan nilai kuat geser tanah $(\tau)$ dibandingkan dengan gaya yang meruntuhkan lereng $(\tau d)$

$$
F S=\frac{\tau}{\tau_{d}}
$$

dengan:

$\tau=$ Kuat geser tanah

$\tau_{d}=$ Tegangan geser yang timbul

$\tau_{d}$ dapat dikatakan sebagai gaya geser yang dibutuhkan untuk mencapai kesetimbangan gaya (menghasilkan $F S=1$ ). Dengan mengunakan kondisi standar Coulomb, faktor keamanan menjadi :

$$
F S=\frac{c-\sigma \tan \phi}{c_{r}-\sigma \tan \phi_{r}}
$$

dengan:

$\varnothing=$ Sudut geser tanah 
$\emptyset_{r}=$ Sudut geser tanah tereduksi

$c=$ Kohesi tanah

$c_{r}=$ Kohesi tanah tereduksi

Seiring berkembangnya metoda numerik dan komputasi berdampak kepada kemajuan pendekatan permodelan masalah geoteknik. Salah satu metode yang familiar digunakan dalam analisis stabilitas lereng adalah metode elemen hingga (Finite Element Method / FEM). Untuk analisis stabilitas dengan FEM, digunakan prosedur phi $-c$ reduction yaitu dengan menurunkan/mereduksi nilai dari sudut geser dalam $(\phi)$ dan kohesi $(c)$ sehingga lereng mengalami keruntuhan. Berdasarkan persamaan (2), metoda phi $-c$ reduction digunakan dalam perhitungan faktor keamanan global (Brinkgreve, 2002) dapat dituliskan dalam formula sebagai berikut:

$\frac{c}{c_{r}}=\frac{\tan \phi}{\tan \phi_{r}}=\sum M s f$

dengan:

$\sum M s f=$ Total Multiplier

$c \quad=$ Kohesi tanah asli

cr $\quad=$ Kohesi tereduksi

$\tan \phi \quad=$ Tangensial sudut geser dalam tanah

$\tan \phi_{r}=$ Tangensial sudut geser dalam tanah tereduksi

Nilai $\sum M s f$ meningkat selama proses kalkulasi hingga lereng mengalami keruntuhan /kegagalan. Angka Keamanan (FS) didefenisikan sebagai nilai $\sum M s f$ pada saat terjadi kegagalan pada lereng.

\section{Perkuatan Tanah Dengan Menggunakan Soil Nailing}

Soil nailing adalah teknik menstabilkan tanah eksisting akibat perubahan kondisi geoteknik, baik akibat perubahan alam atau aktivitas manusia dengan cara menanamkan nail (biasanya beton bertulang) yang berdimensi kecil dengan jarak yang cukup rapat (Han, 2015). Biasanya di alam ketidakstabilan tanah diakibatkan oleh erosi dan presipitasi. Untuk aktivitas manusia, perubahan geometri akibat kebutuhan proyek (galian). Soil nail dapat dapat dipasang pada keadaan eksisting ataupun pada dinding saat proses galian.

Berbeda dengan ground anchor, pada soil nail tidak diberikan prestressed untuk menimbulkan gaya tahanan saat pemasangannya, namun tegangan terbentuk selama waktu layan soil nail akibat pergerakan lereng tanah (Han, 2015). Soil Nailing lebih mengandalkan kekuatan materialnya dalam memikul beban lereng, mirip seperti perkuatan lereng menggunakan material geosintetik.

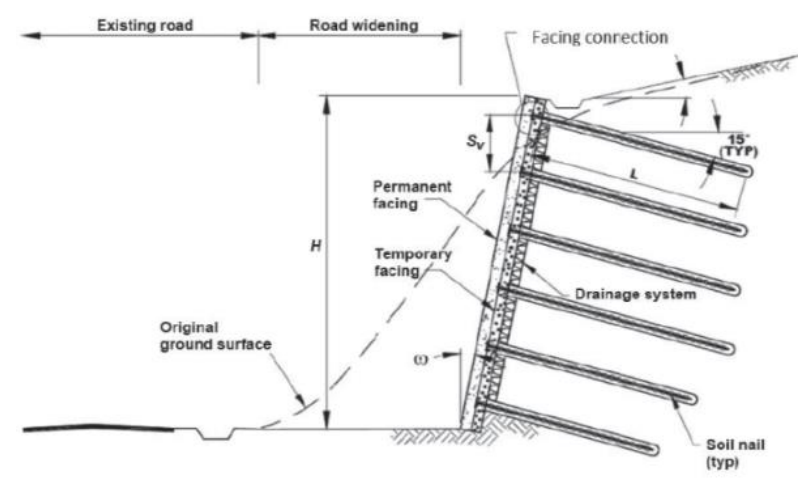

Gambar 1. Tipikal potongan perkuatan lereng menggunakan soil nailing (Han, 2015)

Untuk desain soil nail, perlu diperhatikan beberapa jenis kegagalan yang dapat terjadi. Pada soil nailing terdapat tiga tipe keruntuhan yang dapat terjadi diantaranya:

1. Keruntuhan internal

2. Keruntuhan eksternal

3. Keruntuhan pada facing

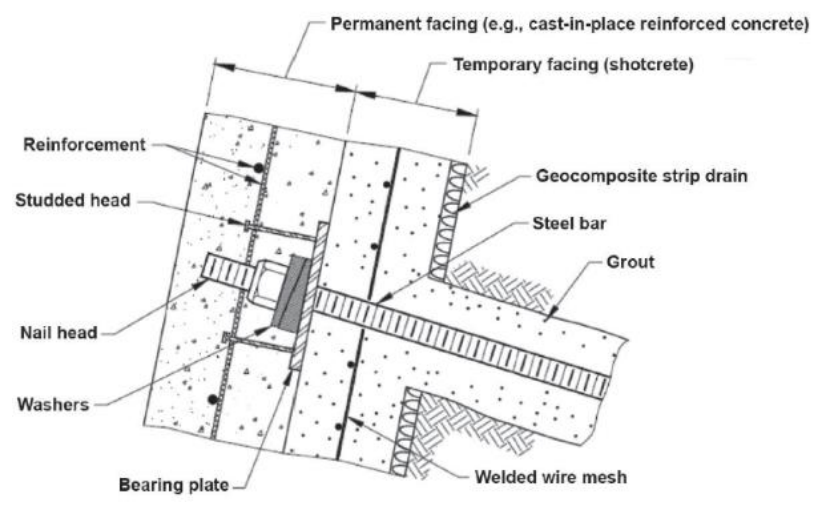

Gambar 2. Detail facing soil nailing (Han, 2015) 


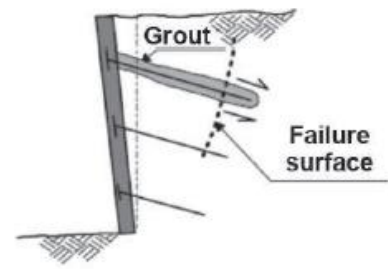

(a) Nail-soil
pullout failure

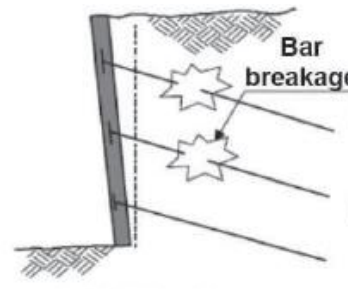

(c) Nail tensile failure

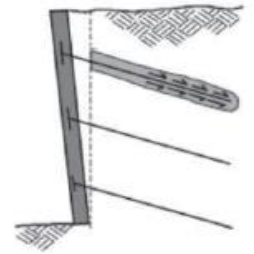

(b) Bar-grout pullout failure

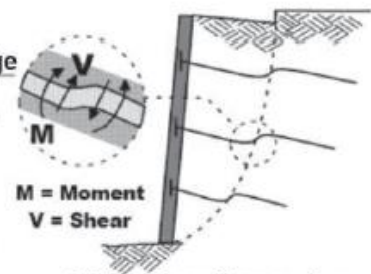

(g) Nail bending and/or shear failure
Gambar 3. Keruntuhan internal pada dinding soil nailing (Han, 2015)

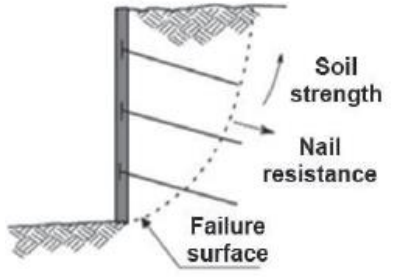

(a) Compound failure

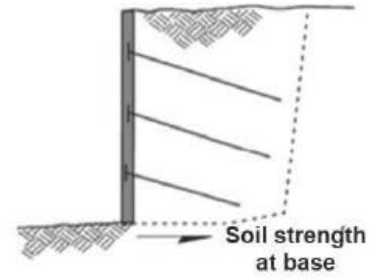

(b) Sliding failure

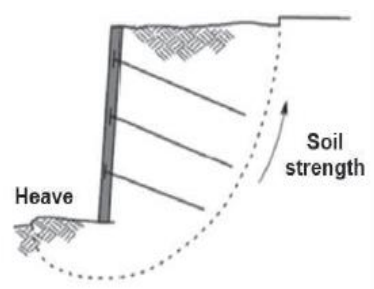

(c) Global failure

Gambar 4. Keruntuhan eksternal pada dinding soil nailing (Han, 2015)

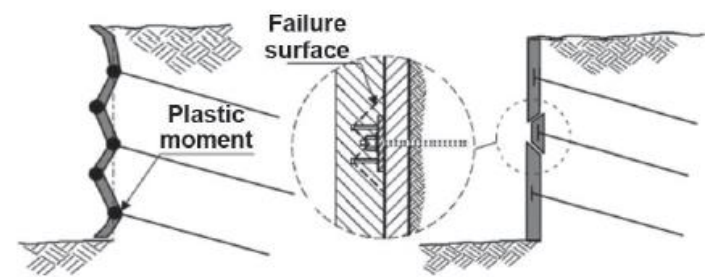

(a) Facing flexure failure (b) Facing punching shear failure

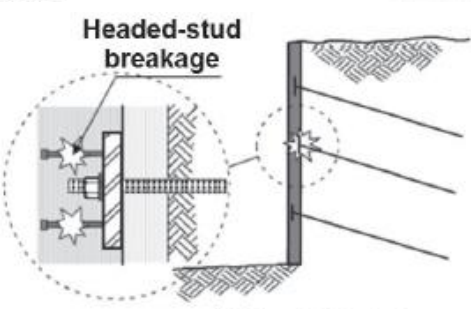

(c) Headed-stud
failure

Gambar 5. Keruntuhan facing pada dinding soil nailing (Han, 2015)
Soil nail biasanya dipasang pada kemiringan 10o sampai 20o, umumnya 15 o (Lazarate, 2015). Untuk sudut pemasangan soil nailing kurang dari 10 o sebaiknya dihindari untuk mencegah terbentuknya rongga pada grout dan "efek paruh burung". "Efek paruh burung" disebabkan karena cairan grout tidak mampu untuk mengisi seluruh rongga pada bagian paling bawah soil nail karena fluiditas grout dan sudut pemasangan yang terlalu landai. Untuk itu perlu dilakukan suatu perlakuan khusus jika ingin memasang soil nailing pada sudut $<10_{0}$ untuk menghindari potensi efek paruh burung tersebut.

\section{Permodelan Soil Nailing Pada Program Elemen Hingga}

Untuk program elemen hingga, tidak ada tools khusus untuk memodelkan perkuatan soil nail. Umumnya, untuk perkuatan lereng dengan soil nailing dimodelkan dengan menggunakan material set plate atau geogrid.

Pada program elemen hingga, material set yang mengabaikan gesekan antara tanah dengan sisi material adalah material set anchor atau node to node. Pada material set node to node, hanya kekuatan material yang dimasukkan sebagai kekuatan dari soil nailing. Gambar 6 dan Gambar 8 merupakan properties kekakuan material yang digunakan untuk memodelkan soil nailing di program elemen hingga.

Hal yang perlu diperhatikan dalam simulasi numerik adalah parameter material yang digunakan. Analisis yang digunakan dalam simulasi ini merupakan simulasi 2dimensi dengan asumsi plane strain. Dengan menggunakan simulasi. Material plate terdapat banyak penyesuaian karena asumsi yang diterapkan pada material set plate berupa material tipis, sedangkan soil nailing memiliki penampang lingkaran. Perlu dilakuakan penyesuaian material set plate dengan soil nailing. 


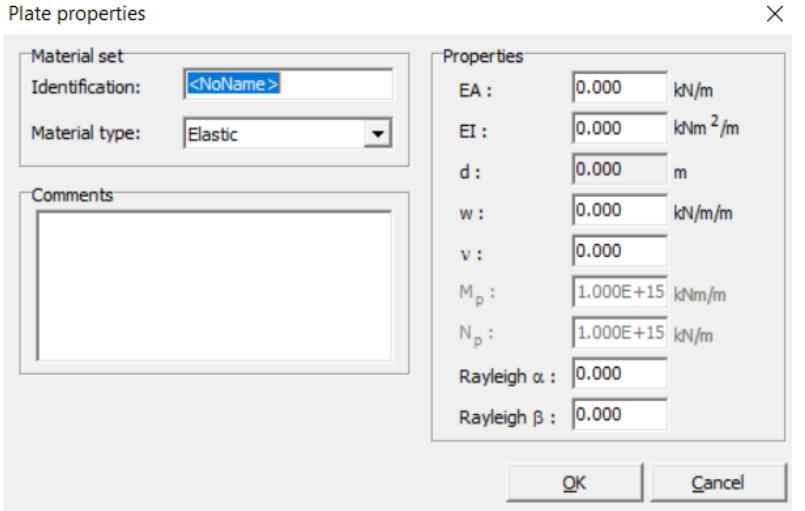

Gambar 6. Properties material plate

Berat spesifik ( $w$ ) pada material set plate merupakan gaya per satuan luas. Pada model elemen hingga, material tanah dan soil nailing saling berimpit, sehingga diperlukan penyesuaian dalam menghitung besarnya $w$. karena $w$ adalah berat dari soil nailing, maka berat tanah yang berimpit dengan plate harus dieliminasi untuk mendapatkan berat plate.

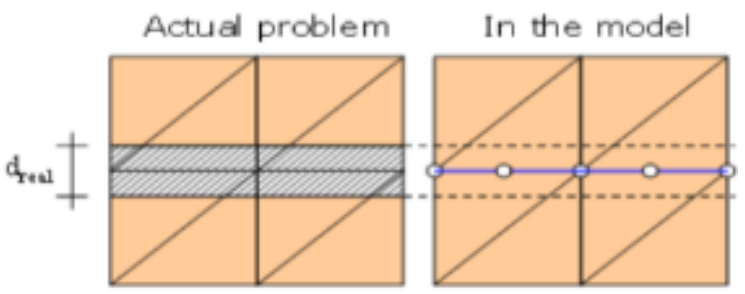

Gambar 7. Aktual dinding dan dinding pada model elemen hingga (Tjie - Liong, 2015)

Nilai $w$ plate dapat dihitung dengan menggunakan persamaan sebagai berikut:

$$
\begin{aligned}
& w_{\text {real }}=\gamma_{\text {beton }} \times d_{\text {real }} \\
& w_{\text {model }}=\gamma_{\text {tanah }} \times d_{\text {real }}+w_{\text {plate }} \\
& w_{\text {model }}=w_{\text {real }} \\
& w_{\text {plate }}=\left(\gamma_{\text {beton }}-\gamma_{\text {tanah }}\right) d_{\text {real }}
\end{aligned}
$$

dengan:

$$
\begin{aligned}
& \text { wreal }=\text { Berat dinding sebenarnya } \\
& w_{\text {model }}=\text { Berat dinding pada model simulasi } \\
& \text { wplate }=\text { Berat material set plate } \\
& \text { rbeton }=\text { Berat isi beton } \\
& \gamma_{\text {tanah }}=\text { Berat isi tanah }
\end{aligned}
$$

Untuk parameter $d$ pada material set plate merupakan ketebalan ekivalen yang didapatkan dari persamaan berikut:

$d=\sqrt{12 \frac{E I}{E A}}$

dengan:

$E I=$ Kekakuan lentur material

$E A=$ Kekakuan aksial material

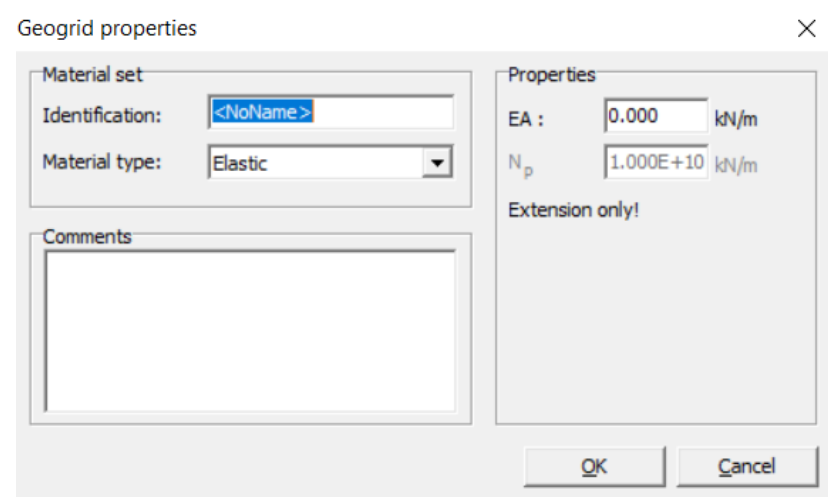

Gambar 8. Properties material geogrid

Karena permodelan menggunakan asumsi plane strain, maka permodelan plate dan geogrid dianggap menerus. Pada kenyataannya soil nailing memiliki jarak antar nail (tidak menerus). Oleh karena itu perlu dilakukan penyesuaian kekakuan ( $E A$ dan $E I)$ pada material set.

$$
\begin{aligned}
& E A_{\text {plain Strain }}=\frac{E A}{S_{H}} \\
& E A_{\text {plain Strain }}=\frac{E I}{S_{H}}
\end{aligned}
$$

dengan:

$S_{H} \quad=$ Spasi horizontal dari soil nailing

Pada material set anchor (node to node) tidak perlu dilakukan penyesuaian kekauan lentur dan kekakuan aksial, karena ada input data Lspacing (spasi arah lateral) pada option material set. 


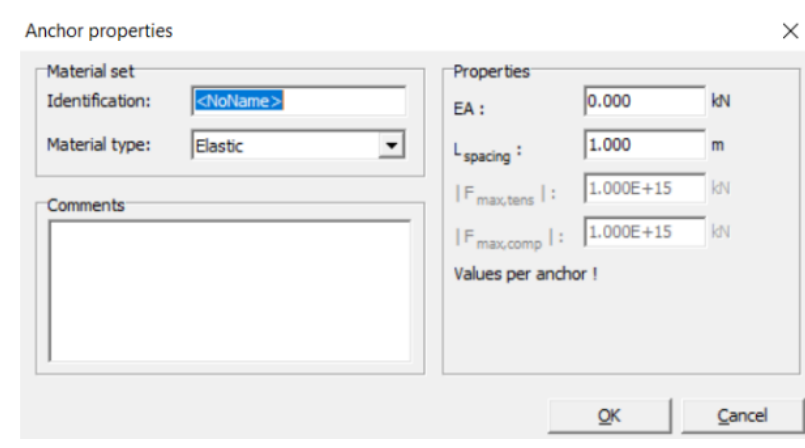

Gambar 9. Properties material anchor (node to node)

\section{METODE PENELITIAN}

Metode penelitian dapat dilihat dari diagram alir penelitian pada Gambar 11. Langkah Pertama yang dikerjakan adalah pengumpulan data sekunder sebagai daerah kajian. Data daerah lereng yang digunakan adalah daerah Suban, Lahat, Sumatera Selatan. Data tersebut didapatkan dari hasil penyelidikan tanah dari suatu proyek penanganan kelongsoran di daerah Suban. Kemudian dari data tersebut, dilakukan analisis kelongsoran menggunakan program limit equilibrium untuk menentukan radius dari bidang gelincir. Radius bidang gelincir ini digunakan untuk menentukan panjang dari perkuatan soil nailing karena panjang yang berperan dalam menahan gaya longsor adalah panjang soil nailing di belakang bidang gelincir.

Setelah mendapatkan bidang gelincir, maka soil nailing dimodelkan masing masing dengan material set berupa plate, geogrid dan anchor/node to node. Variasi pemasangan soil nailing akan dilakukan berdasarkan panjang dan kemiringan pemasangan. Dilakukan 8 variasi panjang (3 $\mathrm{m}, 4 \mathrm{~m}, 5 \mathrm{~m}, 6 \mathrm{~m}, 7 \mathrm{~m}, 8 \mathrm{~m}, 9 \mathrm{~m}$, dan $10 \mathrm{~m}$ ) dan 4 sudut pemasangan terhadap horizontal $\left(0 \mathrm{o}, 10_{\mathrm{o}}, 15 \mathrm{o}\right.$, dan 20o).

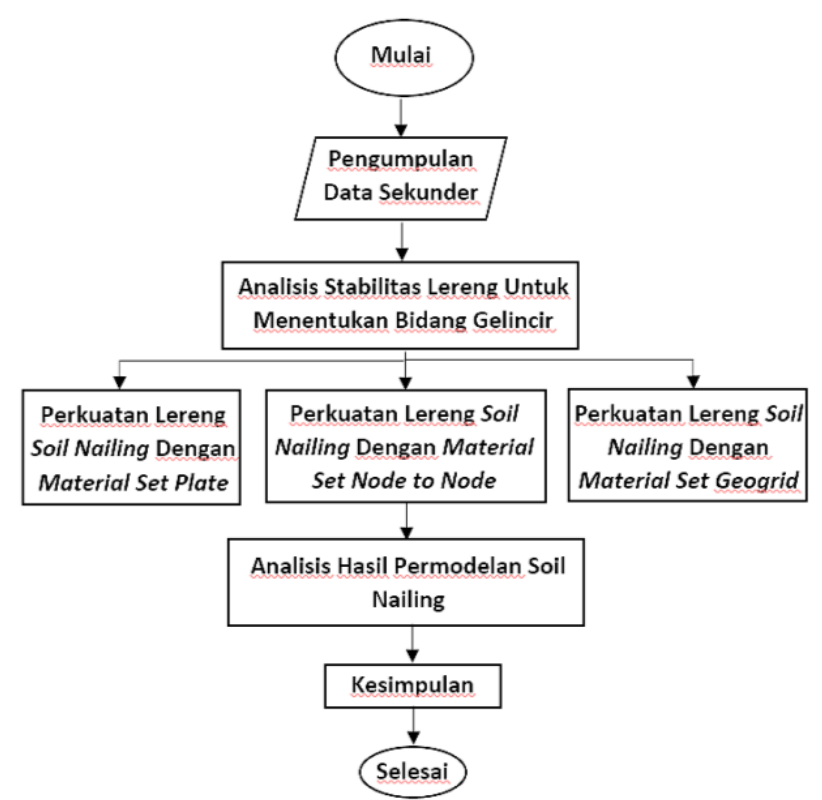

Gambar 11. Diagram alir penelitian

Hasil dari berbagai macam permodelan dirangkum sehingga didapatkan kesimpulan dari pengaruh permodelan material set terhadap hasil $F S$, pengaruh panjang soil nail dan kemiringan terhadap $F S$, dan verifikasi model node to node dapat digunakan sebagai permodelan perkuatan soil nailing.

\section{HASIL DAN PEMBAHASAN}

\section{Analisis Kelongsoran}

Lereng yang digunakan berlokasi di daerah Suban, Lahat, Sumatera Selatan (Gambar 12).

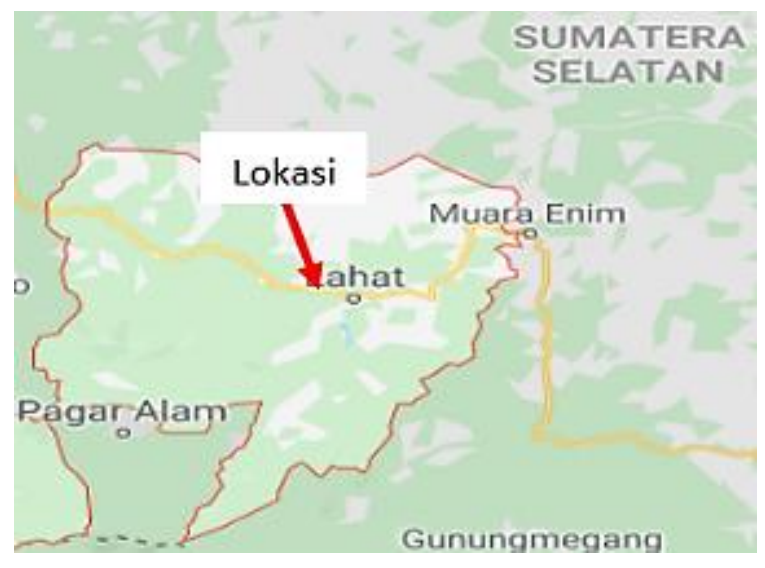

Gambar 12. Lokasi Penelitian

Data tanah didapatkan dari data sekunder yang berasal dari laporan penanggulangan ke 
longsoran di daerah Suban. Tabel 1 adalah data tanah yang digunakan dalam analisis perkuatan lereng berupa parameter indeks properties, kuat geser tanah, dan geometri dan profil melintang dari lereng penelitian.

Data geometri dan profil (Gambar 13), serta kuat geser tanah dianalisis secara limit equilibrium, sehingga didapatkan bidang gelincir yang menjadi datum untuk pertambahan panjang pada perkuatan soil nailing. Beban merata sebesar $15 \mathrm{kN} / \mathrm{m}$ diterapkan sebagai beban layan pada lereng. Metoda yang digunakan adalah Ordinary Method of Slices (OMS). Hasil dari bidang gelincir yang didapatkan dari analisis limit equilibrium dapat dilihat pada Gambar 14.

Tabel 1. Parameter tanah lereng daerah Suban

\begin{tabular}{lccccccccc}
\hline \multicolumn{1}{c}{ Material } & $\begin{array}{c}\gamma_{\text {sat }} \\
\left(\mathrm{kN} / \mathrm{m}_{3}\right)\end{array}$ & $\begin{array}{c}\gamma_{\text {ssat }} \\
\left(\mathrm{kN} / \mathrm{m}_{3}\right)\end{array}$ & $\begin{array}{c}c_{u} \\
(\mathrm{kPa})\end{array}$ & $\begin{array}{c}\phi \\
\left({ }^{\circ}\right)\end{array}$ & $E_{u}(\mathrm{kPa})$ & $v^{\prime}$ & $\begin{array}{c}c^{\prime} \\
(\mathrm{kPa})\end{array}$ & $\phi^{\prime}\left({ }^{\circ}\right)$ & $\begin{array}{c}E^{\prime} \\
(\mathrm{kPa})\end{array}$ \\
\hline Fill Material & 16 & 14 & 36 & 0 & 7200 & 0.35 & 7.2 & 27.05 & 6480 \\
Soft Clays & 14 & 12.5 & 96 & 0 & 19200 & 0.35 & 19.2 & 27.53 & 172080 \\
Silts & 15 & 13 & 134 & 0 & 33500 & 0.35 & 26.8 & 25 & 20100 \\
Hard Clays & 17 & 15 & 360 & 0 & 108000 & 0.3 & 20 & 20 & 64800 \\
Dense Sand & 19 & 17 & - & - & - & 0.3 & 0 & 33 & 17500 \\
\hline
\end{tabular}

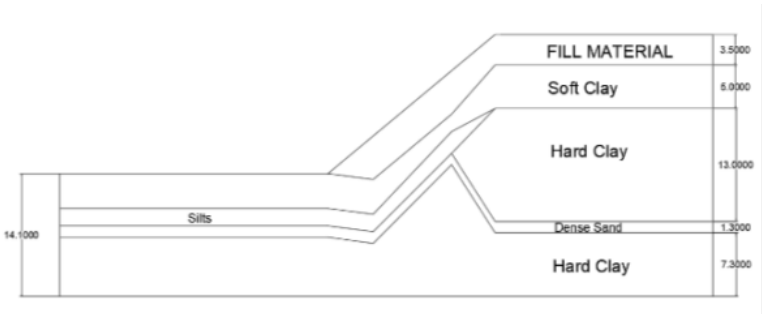

Gambar 13. Geometri dan potongan melintang profil tanah

\section{Perkuatan Tanah dengan Menggunakan Soil Nailing}

Sebelum diberikan perkuatan, nilai $F S$ untuk lereng adalah 1.046. Perkuatan lereng dengan metoda soil nailing akan dimodelkan kedalam tiga jenis material set pada program elemen hingga, yaitu plate, geogrid, dan node to node. Untuk parameter soil nailing dapat dilihat pada Tabel 2 .

Tabel 2. Parameter soil nailing

\begin{tabular}{ccccc}
\hline $\begin{array}{c}E \\
(\mathrm{MPa})\end{array}$ & $\begin{array}{c}D_{\text {soil nailing }} \\
(\mathrm{m})\end{array}$ & $A(\mathrm{~m} 2)$ & $\begin{array}{c}S H \\
(\mathrm{~m})\end{array}$ & $\begin{array}{c}S V \\
(\mathrm{~m})\end{array}$ \\
\hline 200000 & 0.025 & 0.0005 & 1.5 & 1.5 \\
\hline
\end{tabular}

dengan:

E $\quad=$ Modulus elastisitas soil nail

$D_{\text {soil nailing }}=$ Diameter soil nail

A $\quad=$ Luas penampang soil nail

$S_{H} \quad=$ Spasi soil nail arah horizontal
$S_{V} \quad=$ Spasi soil nail arah horizontal

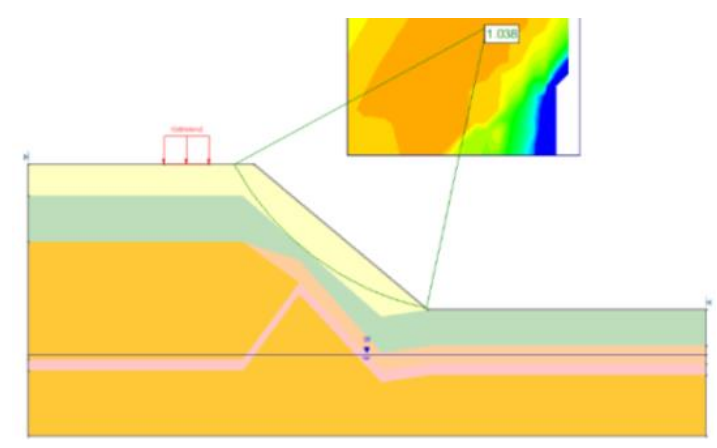

Gambar 14. Bidang gelincir yang terbentuk dengan metode limit equilibrium (metoda OMS)

Tabel 3. Parameter Shotcrete

\begin{tabular}{cccccc}
\hline $\begin{array}{c}f c^{\prime} \\
(\mathrm{MPa})\end{array}$ & $E(\mathrm{MPa})$ & $\begin{array}{c}A \\
(\mathrm{~m} / \mathrm{m})\end{array}$ & $t(\mathrm{~m})$ & $\begin{array}{c}E A \\
(\mathrm{kN} / \mathrm{m})\end{array}$ & $\begin{array}{c}E I \\
(\mathrm{kNm} / \mathrm{m})\end{array}$ \\
\hline 20.75 & 21409.519 & 0.1 & 0.1 & $2.14 \times 106$ & 1784 \\
\hline
\end{tabular}

dengan:

$E \quad=$ Modulus elastisitas shotcrete

$t \quad=$ Tebal shotcrete

$A \quad=$ Luas penampang shotcrete

$E A=$ Parameter kekakuan normal shotcrete

$E I \quad=$ Parameter kekakuan lentur shotcrete

Soil Nailing dimodelkan dengan variasi panjang dan kemiringan. Untuk variasi 
panjang, penanaman soil nailing dan kemiringan dapat dilihat pada Tabel 4 . Panjang soil nail yang dimaksudkan pada Tabel 4 adalah panjang di belakang bidang gelincir, sedangkan untuk kemiringan penanaman adalah sudut yang terbentuk dari bidang datar ke arah soil nailing.

Tabel 4. Variasi perkuatan soil nailing

\begin{tabular}{cllll}
\hline Panjang $(\mathrm{m})$ & \multicolumn{4}{c}{ Sudut $(\mathrm{o})$} \\
\hline 3 & 0 & 10 & 15 & 20 \\
4 & 0 & 10 & 15 & 20 \\
5 & 0 & 10 & 15 & 20 \\
6 & 0 & 10 & 15 & 20 \\
7 & 0 & 10 & 15 & 20 \\
8 & 0 & 10 & 15 & 20 \\
9 & 0 & 10 & 15 & 20 \\
10 & 0 & 10 & 15 & 20 \\
\hline
\end{tabular}

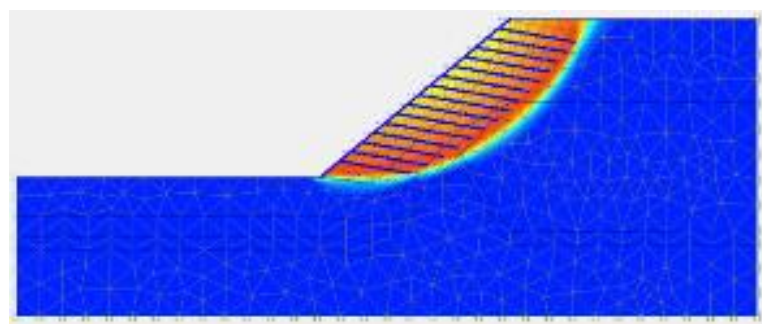

Gambar 15. Contoh permodelan perkuatan lereng dengan menggunakan material set plate

\section{Hasil Permodelan Perkuatan Tanah dengan Menggunakan Soil Nailing}

Hasil perkuatan lereng menggunakan soil nailing dengan material set plate, geogrid, dan node to node dapat dilihat pada Gambar 16 sampai dengan Gambar 19 dan Tabel 5. Berdasarkan hasil permodelan, dapat dilihat perilaku material node to node mendekati hasil FS dengan material set geogrid. Namun, ketiga material set akan memiliki hasil yang mendekati jika sudut pemasangan soil nail dinaikkan. Hal ini dapat dilihat pada sudut pemasangan 15 o dan 20 o, nilai $F S$ dari ketiga model material set hampir mendekati, dimulai dari sudut pemasangan soil nailing 15 o.

Berdasarkan hasil tersebut, juga dapat dilihat bahwa model dengan material set plate memiliki nilai $F S$ yang lebih kecil dibandingkan yang lainnya. Dari kesamaan hasil antara geogrid dan node to node, dapat dikatakan bahwa perilaku soil nailing menyerupai perlaku dinding geosintetik dalam memperkuat lereng. Perbedaan antara hasil FS dari material set geogrid/node to node dengan plate adalah sebesar $0.02 \%-5.12 \%$.

Pada Tabel 5. dapat dilihat pengaruh dari variasi panjang dan kedalaman serta pengaruh pemodelan material set node to node, geogrid, dan plate. Dapat dilihat bahwa semakin miring dan semakin panjang soil nail, maka akan semakin besar $F S$ yang dihasilkan. Kenaikan nilai FS signifikan terjadi pada sudut 0 o sampai 15 o, sedangkan pada sudut 15 o ke 20。 kenaikan nilai $F S$ yang terjadi tidak terlalu signifikan, yaitu sebesar 1\% - 5\%. Soil nailing biasanya dipasang pada kemiringan 10 o sampai 20o, umumnya 15o (Lazarate, 2015). Berdasarkan Tabel 5 juga dapat disimpulkan bahwa sudut pemasangan soil nail yang ideal pada kasus ini adalah pada kemiringan $15 \mathrm{o}$.

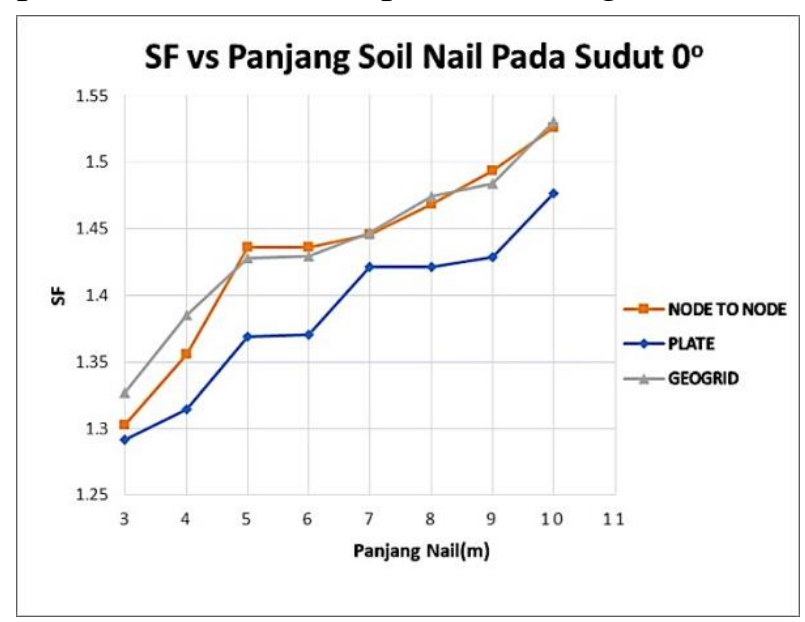

Gambar 16. Nilai faktor keamanan terhadap panjang perkuatan soil nailing pada sudut 0 。 


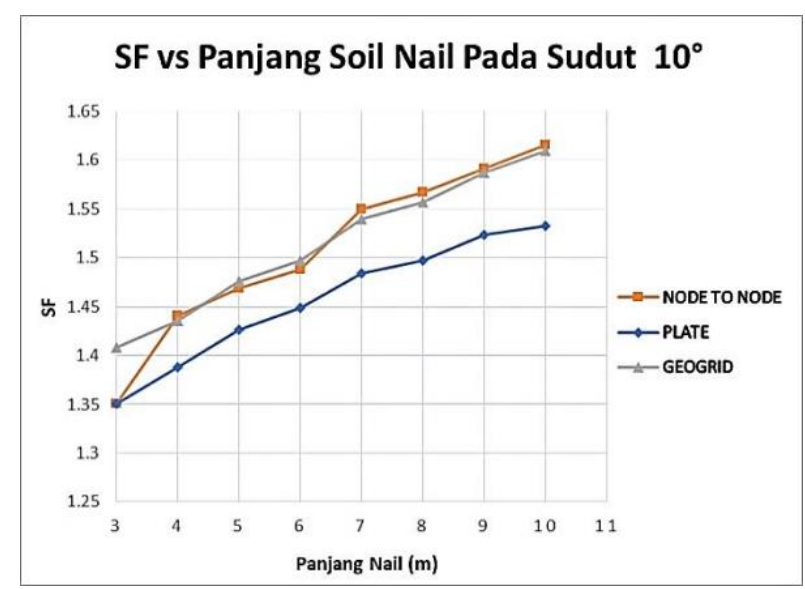

Gambar 17. Nilai faktor keamanan terhadap panjang perkuatan soil nailing pada sudut 10 o

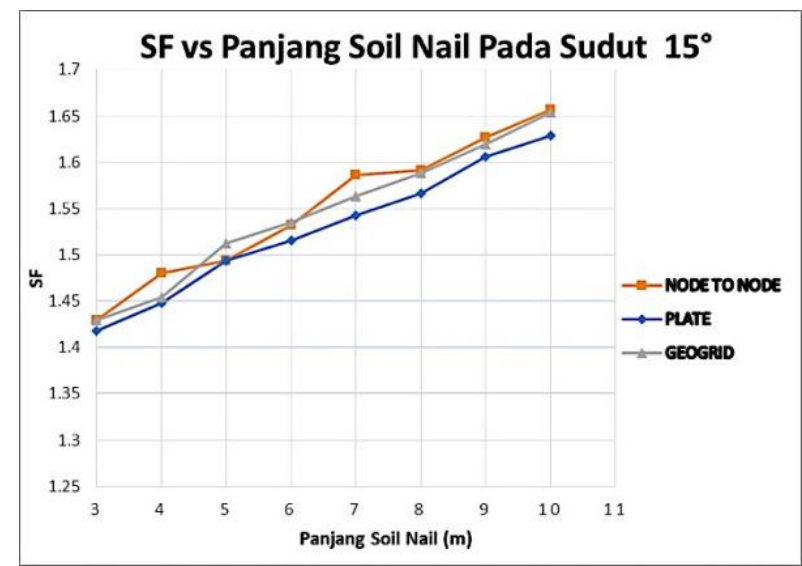

Gambar 18. Nilai faktor keamanan terhadap panjang perkuatan soil nailing pada sudut 15 。

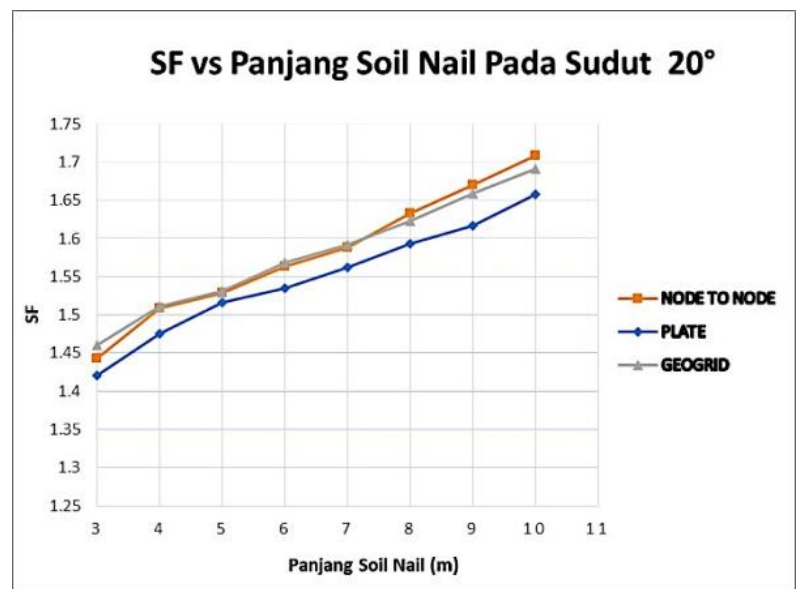

Gambar 19. Nilai faktor keamanan terhadap panjang perkuatan soil nailing pada sudut 20 。

Tabel 5. Pengaruh variasi perkuatan soil nailing terhadap $F S$ sebelum diperkuat

\begin{tabular}{|c|c|c|c|c|c|c|c|c|c|}
\hline \multirow{2}{*}{ Sudut } & \multirow{2}{*}{$L$} & \multicolumn{3}{|c|}{ Kenaikan FS akibat perkuatan (\%) } & \multirow{2}{*}{ Sudut } & \multirow{2}{*}{$L$} & \multicolumn{3}{|c|}{$\begin{array}{c}\text { Kenaikan FS akibat perkuatan } \\
(\%)\end{array}$} \\
\hline & & Anchor & Geogrid & Plate & & & Anchor & Geogrid & Plate \\
\hline \multirow{8}{*}{0} & 3 & 24.474 & 27.151 & 23.327 & \multirow{8}{*}{15} & 3 & 36.711 & 36.711 & 35.755 \\
\hline & 4 & 29.627 & 32.428 & 25.650 & & 4 & 41.530 & 39.044 & 38.442 \\
\hline & 5 & 37.266 & 36.539 & 30.889 & & 5 & 42.782 & 44.598 & 42.801 \\
\hline & 6 & 37.285 & 36.683 & 30.985 & & 6 & 46.434 & 46.816 & 44.866 \\
\hline & 7 & 38.231 & 38.317 & 35.908 & & 7 & 51.597 & 49.446 & 47.505 \\
\hline & 8 & 40.392 & 40.985 & 35.908 & & 8 & 52.094 & 51.845 & 49.713 \\
\hline & 9 & 42.792 & 41.883 & 36.587 & & 9 & 55.488 & 54.857 & 53.489 \\
\hline & 10 & 45.880 & 46.319 & 41.195 & & 10 & 58.346 & 58.098 & 55.707 \\
\hline \multirow{8}{*}{10} & 3 & 29.063 & 34.799 & 29.063 & \multirow{8}{*}{20} & 3 & 37.667 & 39.579 & 35.755 \\
\hline & 4 & 37.696 & 37.247 & 32.706 & & 4 & 44.245 & 44.426 & 41.033 \\
\hline & 5 & 40.468 & 41.099 & 36.396 & & 5 & 46.090 & 46.405 & 44.933 \\
\hline & 6 & 42.294 & 43.088 & 38.528 & & 6 & 49.436 & 49.876 & 46.788 \\
\hline & 7 & 48.136 & 47.208 & 41.845 & & 7 & 51.797 & 52.161 & 49.388 \\
\hline & 8 & 49.790 & 48.862 & 43.164 & & 8 & 56.080 & 55.191 & 52.266 \\
\hline & 9 & 52.132 & 51.711 & 45.631 & & 9 & 59.618 & 58.623 & 54.618 \\
\hline & 10 & 54.436 & 53.843 & 46.530 & & 10 & 63.337 & 61.625 & 58.442 \\
\hline
\end{tabular}




\section{KESIMPULAN}

Berdasarkan pada hasil simulasi numeric, dapat disimpulan bahwa kemiringan ideal permodelan soil nailing adalah 15o. Hal ini dapat dilihat dari kenaikan nilai $F S$ tidak terlalu signifikan saat kemiringan 15 o ke 20。 Kenaikan nilai $F S$ yang terjadi hanya sebesar 1\%-5\%. Untuk simulasi numerik menggunakan material set geogrid dan plate, dibutuhkan koreksi untuk parameter kekakuannya, sehingga perlu diperiksa input nilai kekakuan dari material. Untuk material set anchor tidak memerlukan nilai kekakuan material, tidak perlu dikoreksi karena memasukkan nilai spasi tiang arah horizontal (out of plane). Dari hasil simulasi, penggunaan material set anchor (node to node) bisa mewakili soil nailing dan menghasilkan nilai yang mendekati geogrid. Penggunaan material set lebih konservatif menggunakan plate sebagai material set dari perkuatan lereng menggunakan soil nailing karena menghasilkan nilai FS yang lebih kecil dibandingkan yang lainnya.

\section{UCAPAN TERIMA KASIH}

Segala puji dan syukur Kami haturkan hanya untuk Allah SWT, karena rahmat dan hidayah-Nya, Penulis dapat menyelesaikan artikel ilmiah ini. Terima kasih kepada seluruh rekan - rekan dari Institut Teknologi Sumatera yang telah membantu dalam penyusunan artikel ilmiah ini.

\section{REFERENSI}

Ameratunga, Jay., Sivakugan, N., Das, B.M., 2016. Correlations of Soil and Rock Properties in Geotechnical Engineering, Springer, New Delhi.

Badan Standarisasi Nasional, 2017. Standar Nasional Indonesia - Persyaratan Perancangan Geoteknik, BSN, Jakarta.

Brinkgreve, R.B.J, 2002. Plaxis Version 8: Reference Manual, A.A. Balkema Publishers, Netherlands.

Han, Jie., 2015. Principles and Practices of Ground Improvement, Wiley and Sons, Inc.Ames, New Jersey.

Jayanandan, Midhula., Chandrakaran, S., 2015. Numerical Simulation of Soil Nailed Structures, International Journal of Engineering Research \& Technology (IJERT). 4 (8) : 525 - 530.

Lazarate, Carlos., Robinson, Helen., Gomez, J.E., Baxter, A.,Cadden, A., Berg, R., 2015. Geotecnical Engineering Circular No.7, Soil Nail Wall - Reference Manual, National Highway Institute Course no. 132085.

Ortigao, J.A.R., Sayao A.S.F.J., 2004. Handbook of Slope Stabilisation, Springer, Berlin.

Tjie-Liong, Gouw, 2015. Common Mistakes on the Aplication of Plaxis $2 D$ in Analyzing Excavation Problems, International Journal of Applied Engineering Research. 9 (21) : 8291 8312. 